\title{
Effect of expressive writing Pattern on the decreasing of rumination, depression and stress in divorced women
}

\author{
Farnaz Atarezaei ${ }^{1}$, Yousef Gorji ${ }^{2}$ \\ 1-Master of Psychology, Department of Psychology, Khomeinishahr Branch, Islamic Azad University, \\ Khomeinishahr / Isfahan, Iran. \\ 2- Assistant Professor, Department of Psychology, Khomeinishahr Branch, Islamic Azad University, Khomeinishahr \\ / Isfahan, Iran (Corresponding Author). E-mail: yousefgorgis@yahoo.com
}

Received: 20/04/2020

Accepted: 29/06/2020

\begin{abstract}
Introduction: Ruminantion is one of the most important components of depression which has been considered as an important factor in creation and maintanance of depressed mood over two decades.

Aim: The purpose of this study was to determine the effect of the expressive writing pattern in decrease of rumination and depression, and stress in divorced women of Shahin Shahr.

Method: This research was a semi experimental design with a pretest-posttest design. The population was all divorced women of the welfare organization who had been referred to counseling centers of Shahin Shahr in 2017. Simples sampling were selected and randomly assigned in to two experimental (15) and control (15) groups. The experiment group was trained in 4 sessions under the group's training of writing pattern. The subjects of both groups were evaluated in two stages, pre-test and post-test by the Dass and ruminal questionnaire -reflection. the Data were analyzed by paird t-test, independent t-test and covariance analysis.

Results: The results of this study showed that writing expression pattern significantly decreased the depression, stress, and rumination in divorced women $(\mathrm{P}<0.001)$.

Conclusion: The expression writing pattern intervention is an effective method for decreasing depression and stress and rumination of divorced women. Therefore it can be used as a method in order to treat and reduce the psychological consequences of divorce.
\end{abstract}

Keywords: Expressive writing pattern, Rumination, Depression, Stress, Divorced women

How to cite this article : Atarezaei F, Gorji Y. Effect of expressive writing Pattern on the decreasing of rumination, depression and stress in divorced women. Shenakht Journal of Psychology and Psychiatry. 2020; 7 (3): 76-86 .URL: http://shenakht.muk.ac.ir/article-1-730-en.pdf

Copyright () 2018 the Author (s). Published by Kurdistan University of Medical Sciences. This is an open access article distributed under the terms of the Creative Commons Attribution-Non Commercial License 4.0 (CCBY-NC), where it is permissible to download, share, remix, transform, and buildup the work provided it is properly cited. The work cannot be used commercially without permission from the journal. 


\section{اثربخشى الكوى نكارش بيانكر در كاهش نشخوار فكرى، افسردى و استرس زنان مطلقه}

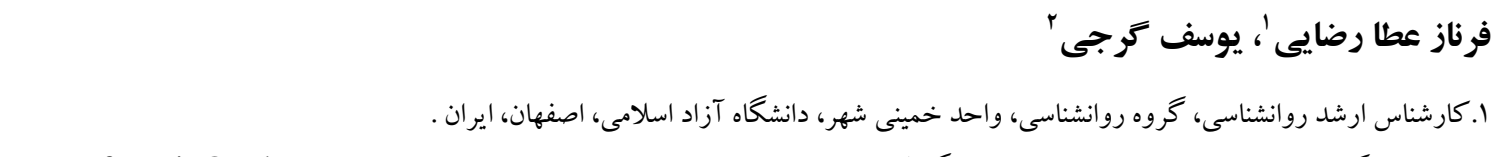

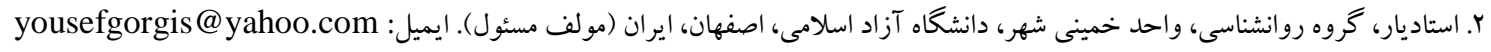

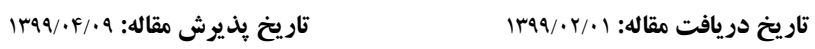

جكيده

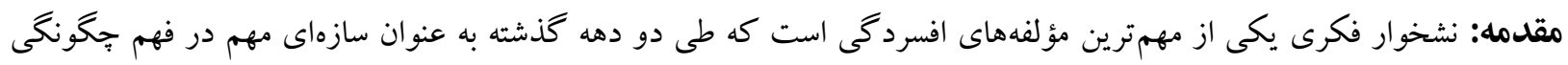

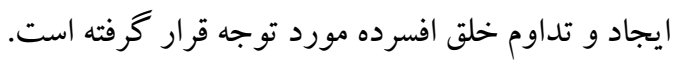

هدف: هدف از اين يُزوهش تعيين اثربخشى الكوى نگارش بيانكر در كاهش نشخوار فكرى، افسردگى و استرس زنان مطلقه شاهين

شهر بود.

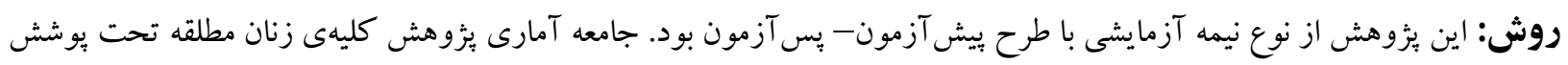

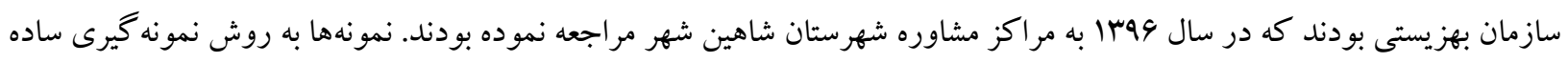

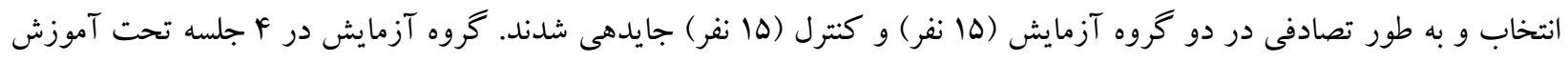

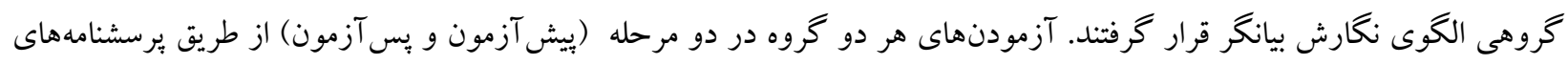

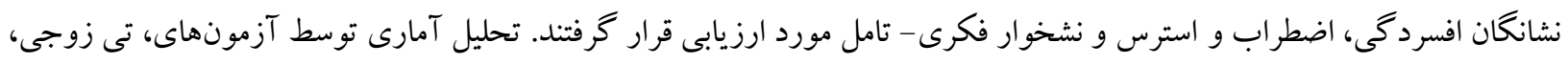
تى مستقل و تحليل كواريانس انجام شد.

يافتها: نتايج يزوهش نشان داد كه آموزش الكوى نگارش بيانگر موجب كاهش معنىدارى در ميزان افسردگى، استرس و نشخوار فكرى در زنان مطلقه شده است (P) (P> (P).

نتيجه كيرى: مداخله الكوى نخارش بيانگر نقش مؤثرى بر درمان افسردگى، استرس و نشخوار فكرى زنان مطلقه دارد؛ بنابراين مى توان از اين روش براى درمان و كاهش ييامدهاى روانى طلاق استفاده كرد. كليدوازهها: الكوى نغارش بيانگر، نشخوار فكرى، افسردگى، استرس، زنان مطلقه 
اثرات كو تاه مدت و بلند مدت طلاق بر زنان، اين نتيجه به دست آمد كه زنان مطلقه نسبت به زنان متأهل به طور معنادارى در سالهاى اول بعد از طلاق سطوح بالاترى از استرس و بريشانى روانى و در يك دهد بعد سطوح بالاترى از بيمارى را نشان مىدهند. علاوه بر اين زنان

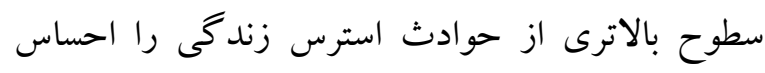

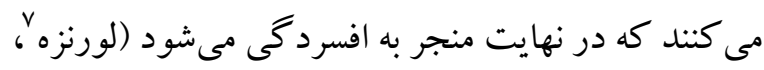

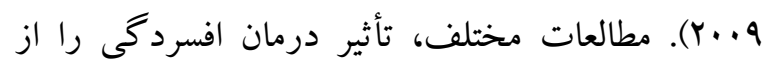
طريق روشهاى دارويى و غير دارويى بررسى نمودهاند. يكك نگرانى عمده در مورد درمان دارويى افسردگى، عوارض جانبى آنهاست به طورى كه برخى بيماران، ناتوان از تحمل هر داروى ضد افسردگى هستند (كارلنر ؛ و (Y.IV توسط تمام داروهاى روانيزشكى و احساس عدم رغبت به مصرف اين داروها است؛ لذا روشهاى غير دارويى مختلف جهت درمان اين بيماران در تمام دنيا از جمله كشور ما مورد استقبال قرار مى گيرد. روشهاى غير دارويى جهت كاهش ميزان اضطراب، اداره استرس، درمان افسردگى و افزايش كيفيت زندگى مورد استفاده قرار مى گيرد. همجينين مشخص شده كه نوشتن و و برونريزى اثرات درمانهاى ديخرى جون رواندرمانى و

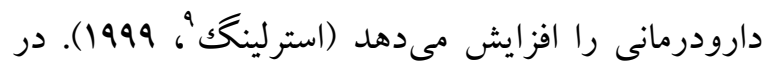
جندين مطالعه انجام شده اين نتيجه به دست آمد كه برونريزى احساسات و هيجانات به صورت نوشتن در مورد حوادث دردناكك و هيجانى مىتواند اضطراب و افسردگى را كاهش دهد، بخصوص زمانى كه همراه با درك عمق هيجانات مرتبط با رويداد، بازبينى و علت يابى و ايجاد بصيرت نسبت به آن بوده و دليل آن آموختن

7. Lorenz

${ }^{8}$ - Gartlehner

${ }^{9}$ - Esterling

\section{مقلمهد}

طلاق بديدهاى فرهنگى و اجتماعى بوده كه امروزه توجه بسيارى از انديشمندان را به خود جلب كرده است. طلاق

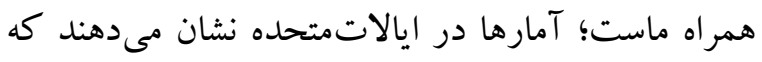
حدود •F- ••ه درصد از ازدواجها به طلاق مىانجامد و فرزندان بايد با شرايط جديد خود را سازگار نمايند

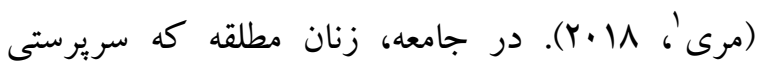

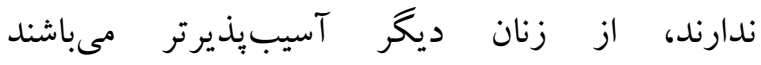

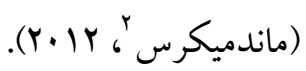
بيشتر اين مشكلات از يكك سو به وسيله جامعه و خانواده و از سوى ديخر به وسيله مسائل اقتصادى بر آنها تحميل شده و باعث مىشود كه آنها تحت فشارهاى روانى

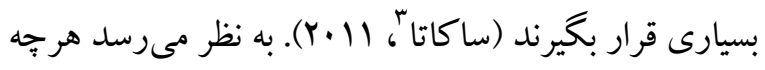
مدت بيشترى از طلاق كذشته باشد ميزان افسردگى نيز

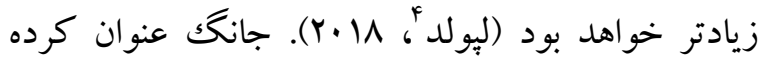
است كه سلامت روانى در غرب بيش درآمد موفقيت زناشويى است (جانگگ تحقيقات يراكندهاى انجام شده است. آنها تحقيقى درباره وضعيت زناشويى و افسردگى در كره انجام دادند. در اين تحقيق س...ه زن شركت داشتند. نتايج بيانكر آن است كه افسردگى در زنان مطلقه و بيوه بيشتر از زنان متأهل است. يبامد منفى طلاق شامل نقص سيستم ايمنى، اختلالات اضطرابى، سوء مصرف مواد، خودكشى، تغيير در سبك زندكى و تصور از خود، كاهش عملكرد حرفهاى، تغيير در روابط اجتماعى و كاهش حمايت

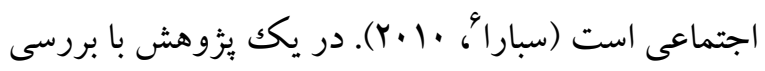

\footnotetext{
1. Marry

2- Mandemakers

${ }^{3}$ - Sakata

${ }^{4}$ - Leopold

5 - Jang

6. Sbarra
} 
يرسشنامه نشخوار ذهنى - تأمل ${ }^{4}$ (R-RS) است. همجنين معيار خروج از مطالعه شامل: عدم تمايل زنان مطلقه به شركت در جلسات و داشتن مشكلات حاد روانشناختى و شخصيتى بود كه از طريق برونده آنان در مراكز مشاوره و انجام مصاحبه با آزمودنىها اعمال گرديد. در اين

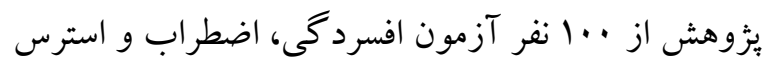

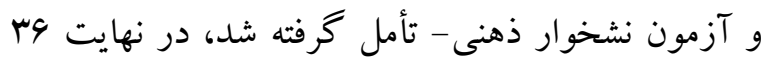

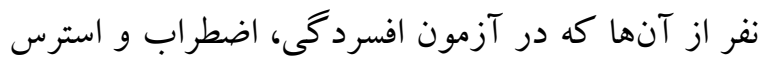
نمرهى بالاتر از •r و در آزمون نشخوار ذهنى - تأمل نمره بالاتر از VY كسب كرده به اين تحقيق راه بيدا كردند. در

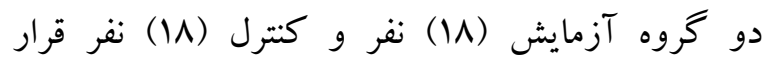

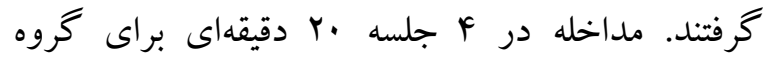
آزمايش انجام شد. به اين صورت كه جلسات گروهى در

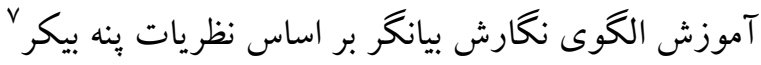

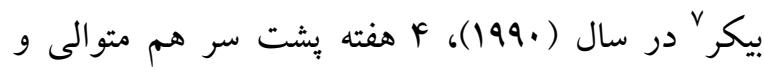
هفتهاى يكك جلسه برگزار شد. در حين انجام كار ب نفر از افراد گروه آزمايش از حضور در اين جلسات انصراف

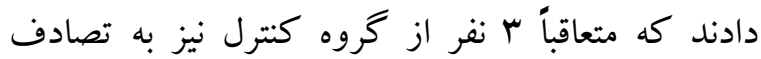
حذف شدند؛ لذا در هر دو گروه ها نفر مورد بررسى قرار گرفتند. مداخله آموزشى در اين مطالعه بدين صورت بود كه از شركت كنند كان خو استه شد كه طى يك مر ماه، هر هفته در يكك ساعت مشخص به مدت ها الى •بم دقيقه به صورت نوشتارى به افشاى هيجانى خاطرههاى ناخوشايند خود در منزل و در يكك اتاق خلوت ببردازند. همجنين بر گهاى تكليف و بركههاى ياد يار براى

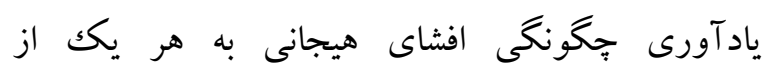

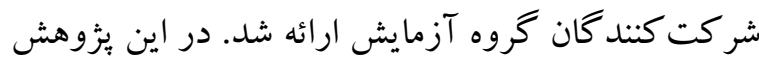
تا حد امكان پِخوراندى به شركت كنند كان ارائه نشد،

${ }^{6}$ - Rumination-reflection scale (R-RS)

7. Pennebaker
فر آيند مدلى و حمايتخرى هماند روان درمانى جهره به جهره توسط خود شخص عنوان شده است (ياتل'

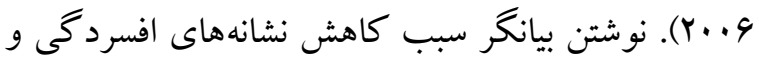

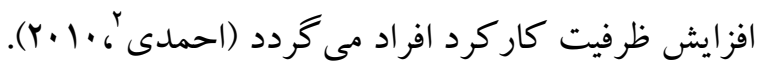

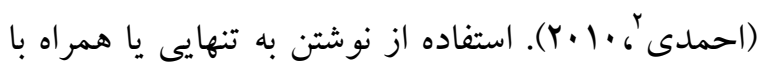
ساير روشهاى درمانى بهطور قابل توجهى در سالهاى اخير افزايش داشته است. مطالعات مختلف نشان داده است كه نوشتن در مورد تجربيات و يا مشكلات عاطفى

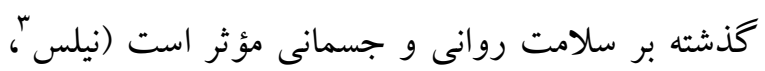

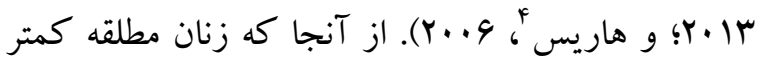
مىتواند در خصوص زندگى خود و قصه زندگى هاسى خويش با ديخران صحبت كنند؛ لذا نوشتن آنها مىتواند به عنوان يكك روش درمان محسوب كردد. حال با توجه به موارد كفته شده و ويامدهاى منفى نشخوار كرى، در اين مطالعه به بررسى اين نكته برداخته شده است كه آيا

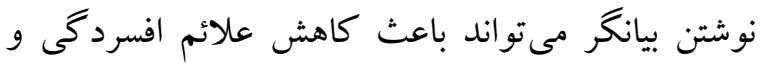

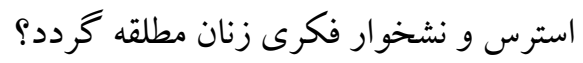

\section{روش}

اين مطالعه از نوع نيمه آزمايشى با طرح ييش آزمون-بس آزمون بود كه روى زنان مطلقهى شاهينشهر در سال

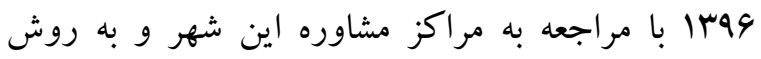
نمونه كيرى ساده انجام شد كه تعداد نمونه ·ب نفر انتخاب شدند. معيار ورود در اين مطالعه شامل اعلام رضايت زنان مطلقه جهت شركت در جلسات از طريق تكميل فرم رضايت و كسب نمره بالاى خط برش پبرسشنامه

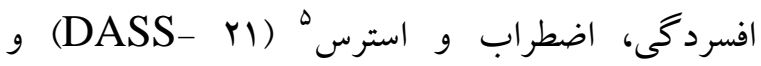

\footnotetext{
1- Patel

2- Ahmadi

${ }^{3}$ - Niles

4- Harris

5- Depression, Anxiety and Stress Scale - 21 Items (DASS-21)
} 
فرايند كار آزمودنىها و تكاليف آنها بررسى شد.

بلكه از طريق برقرارى تماسهاى تلفنى و ملاقات حضورى در F جلسه، هفتهاى Y بار و هر جلسه ها دقيقه،

جدول ا خلاصه محتواى جلسات مبتنى بر آموزش التوى نكارش بيانكر

\begin{tabular}{|c|c|}
\hline محتواى جلسه & جلسه \\
\hline 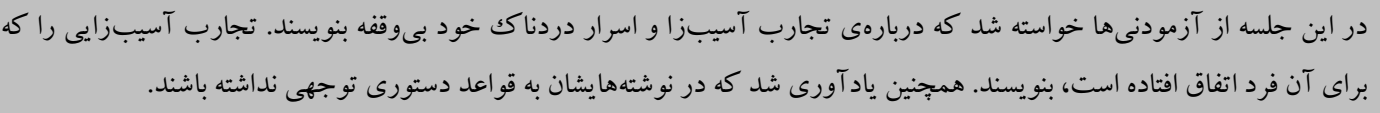 & اول \\
\hline 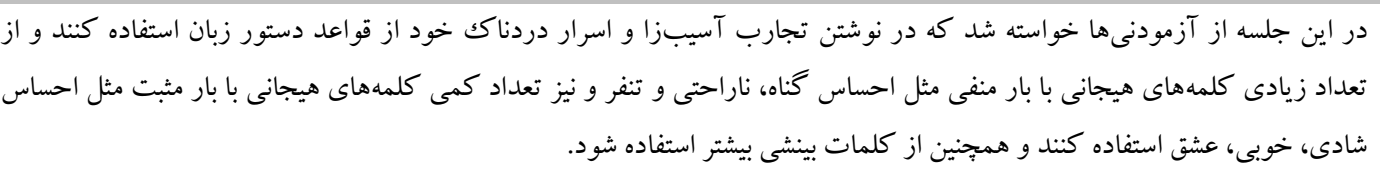 & دوم \\
\hline بودر اين جلسه از آزمودنىها خواسته شد كه به نوشتن دربارمى تجارب آسيبزا و دردناكك خود كه در جلسه اول در مورد آن نوشته & سوم \\
\hline در شخص اين جلسه از آزمودنىها خو استه شد كه در نوشته هايشان از كاربرد ضماير اول شخص اجتناب كنند و همهى جملههاى خود را با سوم & جهارم \\
\hline
\end{tabular}

مى آيد. هر سؤال از صفر (اصلاً در مورد من صدق

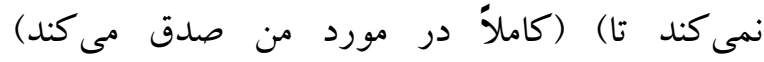

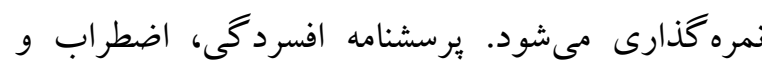
استرس فرم كو تاه شدهى مقياس اصلى (Y Fؤ الى) است. بثزوهشهاى فراوانى به منظور به دست آوردن بايايى و و روائى اين مقياس صورت گرفته است. ضريب آلفاى كرونباخ براى اين مقياس در يكك نمونه هنجارى VIV

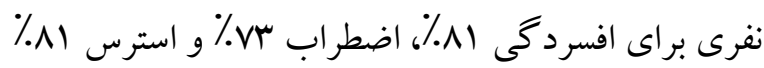

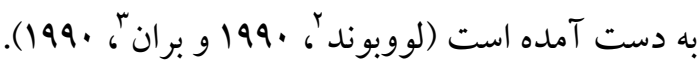

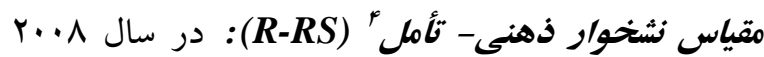
توسط قربانى و همكاران معرفى شده است (قربانىه

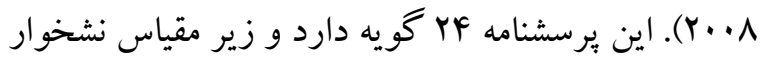
ذهنى و تأمل را در برمى گيرد. نمره گذارى يرسشنامه بر اساس طيف ليكرت ينج درجهاى امتيازبندى شده است.

\footnotetext{
${ }^{2}$ - Lovibond

3 - Brown

4- Rumination-reflection scale (R-RS)

5 - Ghorbani
}

در طى جلسات از آزمودنىها خواسته شد كه با توجه به دستور عمل درمانى هر جلسه به نوشتن در مورد افكار منفى خود ببردازند و شيوههاى مشخص شده در هر جهار جلسه را رعايت كنند. دادههاى اين بزوهش توسط 19 و و آزمونهاى آمارى تى زوجى تى مستقل تحليل كواريانس مورد تجزيه و تحليل قرار گرفتند.

مقياس 'اضسردكى، اضطراب، 'استرس' (DASS):

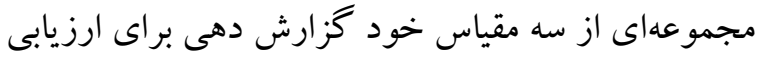
حالات عاطفى منفى در افسردگى، اضطراب و استرس ترسي بود كه در اين مطالعه، قبل و پِ از مداخله در دو گروه

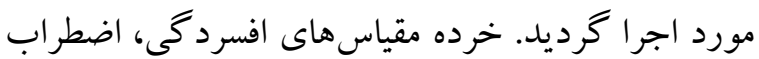
و استرس شامل V سؤال است كه نمره نهايى هر كدام از طريق مجموع نمرات سؤالهاى مربوط به آن به دست

\footnotetext{
'- Depression, Anxiety and Stress Scale (DASS-)
} 
مربوط به گروه سنى •4-ه سال (4/V) براى هر دو

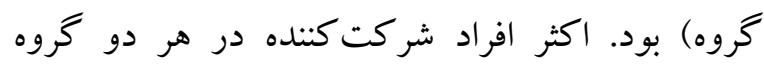

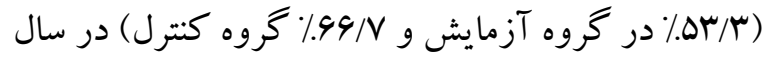

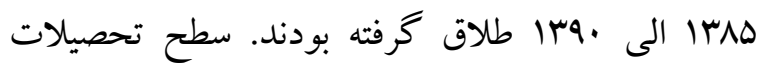
شركت كنند گان در گروه آزمايش و كنترل از دييلم تا حداكثر كارشناسى ارشد بود كه بيشترين درصد فراوانى متغير ميزان تحصيلات شر كت كنند گان در كروه آزمايش

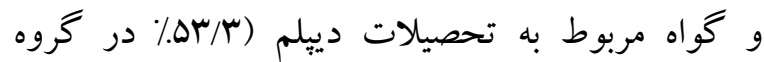

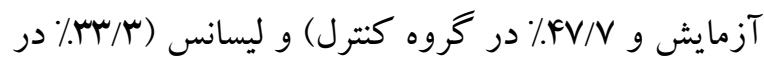
كروه آزمايش و كنترل) گزارش شد. كمترين فراوانى تحصيلات متعلق به گروه فوق ديِلم با 9/V\% در هر دو

$$
\text { كروه بود. }
$$

نمره به دست آمده از هر يكك از مؤلفها را نوشته و تقسيم بر تعداد گويههاى هر مؤلفه مىشود و با هم مقايسه مىشود. نمره هر مؤلفه نشان مىدهد كه ميزان نشخوار

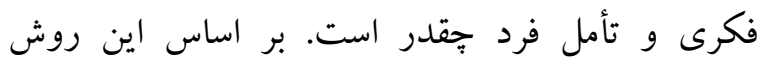
نمرههاى به دست آمده را جمع كرده و سبس قضاوت مىشود. روايى برسشنامه در بُزوهش قربانى و همكاران

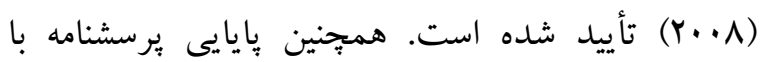
آلفاى كرونباخ بالاى •^^/ به دست آمده است.

\section{يافتهها} در اين مطالعه سن شركت كنند گان در گروه آزمايش و كنترل در محدوده ·r تا •4 سال بود. بيشترين فراوانى در

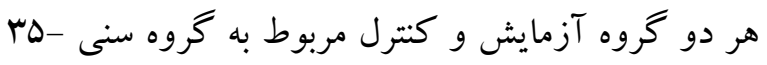

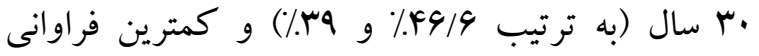

جدول r مقايسه ميانكين و انحراف معيار متغير استرس و افسردحى در تروه آزمايش و كنترل ويش و يس آزمون

\begin{tabular}{|c|c|c|c|c|c|c|}
\hline \multicolumn{3}{|c|}{ افسردگى } & \multicolumn{3}{|c|}{ استرس } & \\
\hline معنادارى آمارى & كروه كنترل & كروه آزمون & معنادارى آمارى & كروه كنترل & كروه آزمون & \\
\hline$\cdot / \Delta \cdot V$ & $19 / \mathrm{V} \pm \mathrm{r} /$. & $19 / 9 \cdot \pm r / 9$ & $\cdot / \Delta \Delta$ & $19 / r V \pm r / V \Lambda$ & $19 / \pi r \pm r / r$ & ييش از آزمون \\
\hline$\cdot / \cdots$ & $10 / 9 \cdot \pm r /$. & $11 / N r \pm r / 9$ & $\cdot / \cdots$ & $10 / A V \pm Y / / q$ & $\mid r / A V \pm r / F$ & پֶ از آزمون \\
\hline$\cdot \ldots$ & $1 / 1 r \pm \cdot / 1$ & $\varphi / A V \pm \cdot / \varphi_{\Delta}$ & $\cdot / \cdots$ & $\cdot / q \pm \cdot / r q$ & $r / 49 \pm \cdot / r$ & تِ بـ از بِ آزمون و \\
\hline
\end{tabular}

ميزان كاهش استرس و افسردگى در گروه آزمايش به طور معنادارى بيشتر از كروه كنترل بود. در نتيجه مى متوان

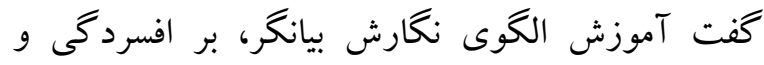

$$
\text { استرس مؤثر بوده است. }
$$

براساس يافتهاى جدول شماره Y، ميزان استرس و افسردكى در كروه آزمايش و كنترل قبل از مداخله

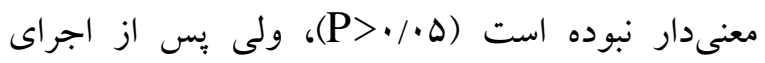
مداخله ميزان استرس و افسردگى در گروه آزمايش به به طور معنادارى كمتر از گروه كنترل بود؛ به عبارت ديخر

\begin{tabular}{|c|c|c|}
\hline معنادارى آمارى & كروه كنترل & كروه آزمون \\
\hline .199 & $q r \pm q / Y q$ & $\cdot / A V \pm g / q V$ \\
\hline
\end{tabular}

جدول ب مقايسه ميانكين و انحر اف معيار متغير نشخوار فكرى در كروه آزمايش و كنترل ييش و پيس از مداخله 


\begin{tabular}{|c|c|c|c|}
\hline$\cdot / \cdots$ & $q r \pm \Delta / \Lambda r$ & $r / 9 \pm \Delta / \Delta r$ & 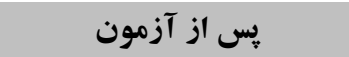 \\
\hline$\cdot / \cdots$ & $9 \pm \cdot / \Delta V$ & $\cdot / r V \pm \cdot / 9 \Delta$ & تفاوت يیش و یِ از آزمون \\
\hline
\end{tabular}

آسيبزا مى تواند باعث توسعه مقابله اثربخش شود و با از بين بردن عواطف منفى ناشى از افكار، منجر به كاهش

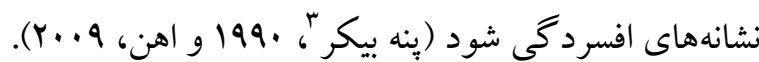

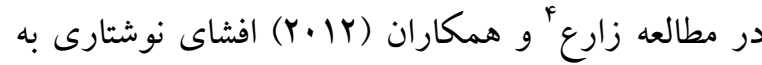
طور معنادارى مدت علائم وسواسى و افسردگى مبتلايان ديخرى نشان داده شد كه برونريزى هيجانها با ساختار نوشتارى در كاهش اضطراب مؤثر است ولى بر ميزان

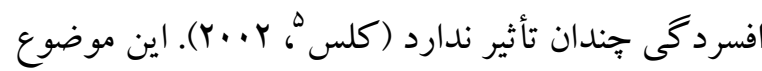
موضوع مغاير با يافتهاى يزوهش حاضر است كه شايد تا يا

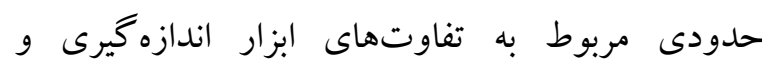
ويز گیىهاى جمعيت نمونه در دو يزوهش باشد. با توجه به اينكه در نغارش بيانگر آزمودنىها در جلسات دوم به بعد نسبت به جلسه اول زمان بيشترى براى نوشتن درخواست مى كردند، مشخص شد كه هيجانات ينهان در آنها آشكار مىشد و با برونريزى بهوسيله نوشتن از هيجانات منفى آنها كاسته شد و با وجود اين كه نوشتن آنها در موارد بسيارى همراه با گريه بود؛؛ اما در انتهاى

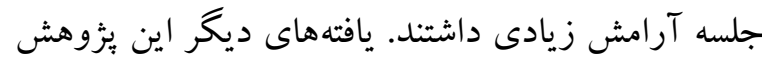

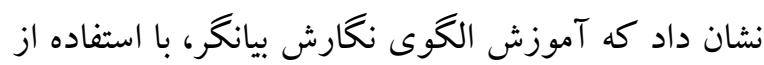
نغارش كتبى احساسات و هيجانات منفى بر كاهش استرس اثربخش است. نتايج به دست آمده نشان داد كه مداخله آموزشى با استفاده از برنامه آموزشى مورد نظر بر بر بـ كاهش استرس زنان مطلقه مؤثر بوده است و با نتايج كزارش شده از برخى يزووهشها همخوانى دارد (براى به اختلال وسواس اجبار را كاهش داده است. در بثوهش

براساس يافتههاى جدول فوق تفاوت ميزان نشخوار فكرى در كروه آزمايش و كنترل قبل از مداخله معنىدار نبود

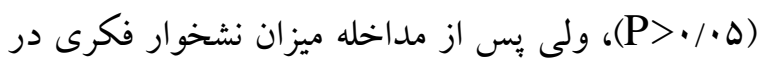
كروه آزمايش به طور معنادارى كمتر از گروه كنترل بودب؛ه عبارت ديخر ميزان كاهش متغير نشخوار فكرى در ارد كروه آزمايش به طور معنادارى بيشتر از گروه كنترل بود.

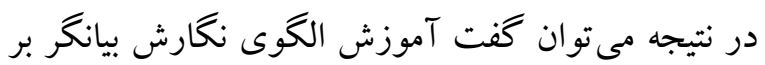
ميزان نشخوار فكرى مؤثر بوده است.

اين ايزوهش با هدف بررسى تأثير نغارش كتبى

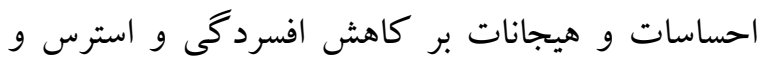
نشخوار فكرى زنان مطلقه شهر شاهينشهر اجرا شد. يافتهاى يثروش نشان داد كه آموزش با استفاده از الكوى نگارش بيانگر بر ميزان افسردگى و استرس و نشخوار فكرى زنان مطلقه مؤثر بوده است و سبب كاهش افسردگى و استرس و نشخوار فكرى آنان شده است. در خصوص تأثير برنامه آموزشى الكوى نگارش بيانگر در كاهش افسردگى آزمودنىها در يافتهاى مطالعه حاضر،

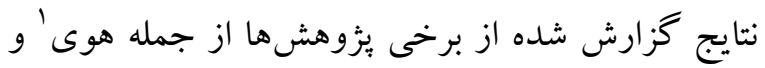

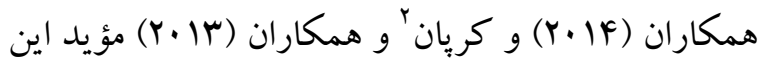
نتايج است. در هر يكك از اين ئزوهشها از زاويهاى متفاوت به اين متغيرها توجه شده است. نگارش بيانگر، بررسى يكك رويداد با بار هيجانى را به صورت روايت در آورده و هيجانات و نكات ناكفته و نامفهوم را در قالب كلمات و معنا در مى آورد. نوشتن درباره رويدادهاى

3. Kahn

${ }^{4}$ - Zareh

5 - Kloss
1- Hevey
2- Krpan 


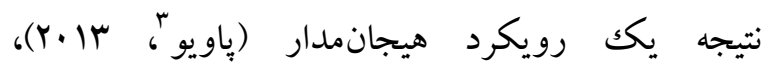
احساسات و هيجانات خود را تخليه كند و تا حدى بتواند

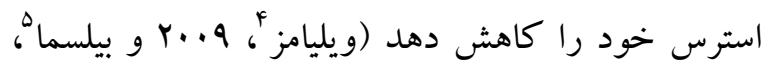

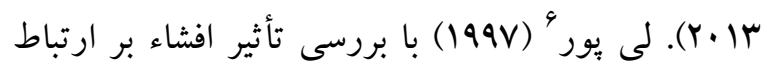

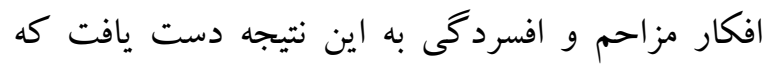
اكرجه افشاى هيجانى نوشتارى فراوانى افكار مزاحم را كم نكرد ولى با تأثير بر روى اين افكار علائم افسردگى إنى را تعديل نمود و كاهش علائم افسردگى را سبب شد.

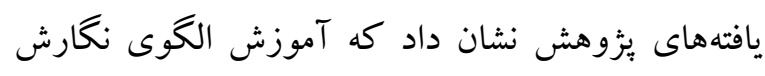
بيانكر با استفاده از نگًارش كتبى احساسات و هيجانات منفى بر كاهش نشخوار فكرى مؤثر است. نتايج به دست آمده نشان داد كه مداخله آموزشى با استفاده از برنامه آموزشى مورد نظر بر كاهش نشخوار فكرى زنان مطلقه مؤثر بوده است. اين يافتها، فرضيه يثزوهشى را تأييد مى كند. نتايج به دست آمده در اين فرضيه با نظريه بازدارى كه بيانگر نقش بازدارى هيجانها در اشغال ظرفيتهاى روانشناختى و تأثير ضد بازدارندكى افشا باردا است، همسو است. بر اساس اين ديدگاه، افشاى هيجانى با شكستن فرايند بازدارى موجب كاهش استرس، مشكلات روانشناختى و جسمانى مىشود. در اين يُخوهش در جلسات اول و دوم هنگامى كه از شركت كنند گان خواسته مىشد در مورد رويداد طلاق بنويسند، اذعان مى كردند كه نمى توانند تمركز كنند. براى جند دقيقه نوشتن را رها مى كردند و به فكر فرو مىرفتند و درگير يكك صحنه تكرارى از رابطه شكست خوردهى خود مىشدند؛ اما هر جهه جلوتر مىرفتند تمركز بيشترى بيدا مى كردند و مىتوانستند روى موضوع طلاق خود

3 - Paivio

4. Williams

5 - Bylsma

6. Lepore

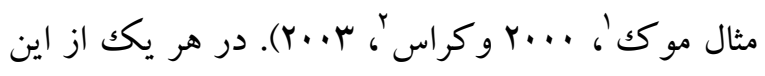
يثزوهشها از زاويهاى متفاوت به اين متغيرها توجه شده است. در نگارش بيانگر احساسات ناكفته و ناخود آكاه به عبارات كفتارى آكاهانه تبديل مىشوند و هر آنجه كه

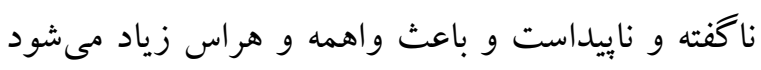
آشكار مىشود و با آكاهى يافتن نسبت به ناكفته ها از

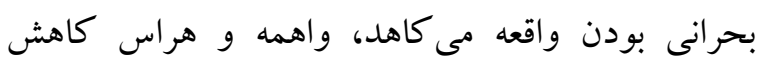

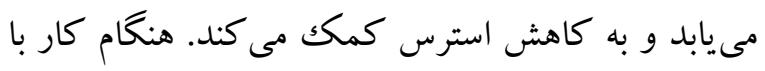
اين افراد بيشترين جيزى كه توجه را به خود جلب كرد

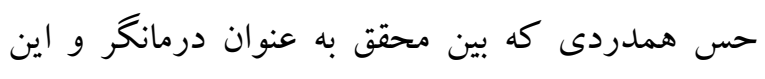
افراد ايجاد شده بود. خيلى از آنها شايد حتى براى يك هـ بار نتوانسته بودند با كسى خود فاشسازى كنند (به صورت كتبى احساسات و عو اطف خود را بر روى كاغذ بلذ بون بياورند) حرفهايى كه شايد افراد در بيان آن راحت نيستند. ولى در اين مورد توانستند هيجانات و احساسات

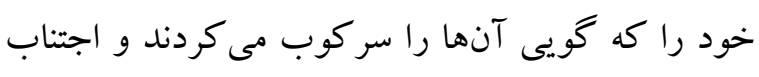
مىنمودند بيان دارند. اين شيوه نوشتن براى آنها نوعى آنى تخليه هيجانى به حساب مى آمد و به مرور در آنها باعث كاهش استرس شد. كاه ديده شد كه تعدادى از آنها حتى در هنگام نوشتن كريستهاند؛ زيرا در آن لحظه كه افكار به صورت جملات بر قلم آورده شده، كويى با

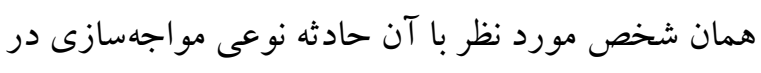
آنها شكل گرفت. شايد در لحظات اوليه دجار استرس بيشترى شدند ولى كم كم به طرف آرامش بيش مىرفتند بهترين كارى كه اين روش براى كاهش استرس آنها انجام داد شايد نوع مواجه سازى با احساسات و هيجاناتى لهري بود كه مدتها در ذهن فرد باقى مانده بود و الان او اين امكان را داشت كه آنها را از طريق نوشتن بيان كند و در برد

\footnotetext{
1 - Mogk

2- Gross
} 


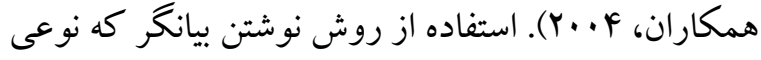
افشاى هيجانات بوده به اين صورت مؤثر واقع مىشود كه باعث شكستن فرايند بازدارى شده و موجب كاهش استرس و مشكلات روانشناختى شده است. فرايند نوشتن در اين روش باعث مىشود تا شخص نسبت به نخر انىها

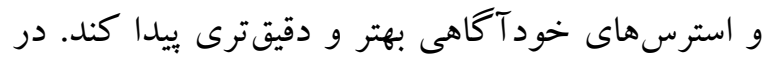
نتيجه براى حل آنها روش مناسبترى را استفاده مى كند و نوشتن باعث مىشود به جز تخليه هيجانى، به درك مناسبترى از وضعيت حال حاضر دست يابد. اين تخليه هيجانى باعث كاهش استرس و افسردكى نشخوار فكرى

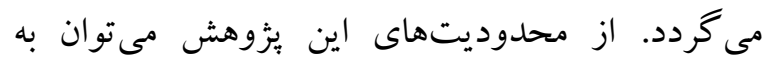
نداشتن مرحله ييخيرى و ارتباط مستمر با مراجعين و عدم اطمينان از يايدارى نتايج اشاره كرد. در ادامه بيشنهاد مىشود اين تحقيق در مورد مردان با شرايط مشابه زنان و

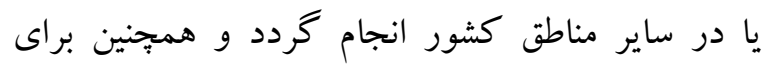
سرفصلهاى آموزش خانواده و يا در كلينيك آموزش

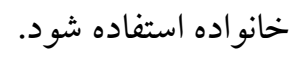

\section{سياسگز ارى}

اين مقاله حاصل بياياننامه دانشجويى كارشناس ارشد روانشناسى دانشگاه آزاد اسلامى واحد خمينى شهر است كه بدينوسيله از اساتيد گرانقدر دانشگاه آزاد اسلامى رواهى واحد خمينىشهر و كليه افراد شركت كننده در مطالعه و تمامى كسانى كه به نحوى در اجراو تكميل اين بيزوهش همكارى داشتهاند، تشكر و قدردانى مى گر دد.

\section{References}

Ahmadi M, Abdollahi MH. (2010). The impact of written emotional expperssion on depressive
تمركز كنند. يافتهاى بثزوهش نشان دهندهى اثربخشى آموزش الكوى نغارش بيانكر بر كاهش افسردگى'، استرس و نشخوار فكرى با استفاده از نخارش كتبى احساسات و هيجانات منفى است. با توجه به اينكه در نغارش بيانگر در زنان مطلقه در جلسات دوم به بعد نسبت به جلسه اول زمان بيشترى براى نوشتن درخواست مى كردند، مشخص شد كه هيجانات بنهان در آنها آشكار مىشود با برونريزى به وسيله نوشتن از هيجانات منفى آنها كاسته شد و با وجود اينكه نوشتن آنها در موارد بسيارى همراه با گريه بود؛ اما در انتهاى جلسه آرامش زيادى داشتند. بهترين كارى كه اين روش براى كاهش استرس انجام داد، مواجه سازى با احساسات و هيجاناتى بود كه مدتها در ذهن فرد باقى مانده بود و الان او اين امكان را داشت كه آنها را از طريق نوشتن

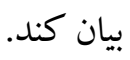

\section{نتيجه كيرى}

در نوشتن بيانگر از شخص خو استه شده تا بهدرستى وقت مناسب صرف نموده و عميق ترين احساسات و افكار خود را كشف كند، آنها را به حالت نوشتارى درآورده، به نوعى مواجهسازى صورت مى گيرد كه مغاير با اجتناب از احساسات و افكار منفى است. در نهايت برونريزى هيجانات و افكار منفى را باعث مىشود. بدين ترتيب نوشتن بيانگر باعث كاهش استرس و افسردگى و نشخوار فكرى در زنان مطلقه مىشود. نوشتن بيانكر با عملكرد برونريزى افكار و هيجانات علاوه بر ايجاد سلامت روان

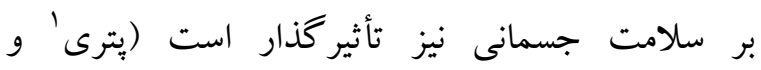

\footnotetext{
1- Petrie
} 
symptomps and working memory capacity in Iranain students with high depressive symptoms.Procedia social and behaviral sciences,5,1510-1514.

Brown TA, Chorpita BF, Korotitsch W, Barlowv D. (1997). Psychometric properties of the depression anxiety stress scales in clinical samples. Behaviour Research and Therapy, 35, (1), 79-89.

Bylsma LM, Rottenberg J. (2011). Uncovering the dynamics of emotion regulation and dysfunction in daily life with ecological momentary assessment. Emotion regulation and well-being,225-244.

Esterling BA, L'Abate L, Murray EJ. (1999). Empirical foundations for writing in prevention and psychotherapy: mental and physical health outcomes. Clinical psychology review, 19(1), 79-96.

Gartlehner G, Wagner G, Matyas N. (2017). Pharmacological and non-pharmacological treatments for major depressive disorder. review of systematic reviews. BMJ Open, 7(6), e.149912.

Ghorbani N, Watson PJ, Hargis MB. (2008). Integrative Self-Knowledge Scale: Comelations and Incremental Validity of a Cross-Cultural Measure Developed in Iran and the United States. The Journal of Psychology, 142(4), 395-412.

Gross JJ, John OP. (2003). Individual differences in two emotion regulation processes: implications for affect, relationships, and well-being. Joumal of personality and social psychology, 85(2), 348362.

Harris AH. (2006). Does expressive writing reduce health care utilization? A meta-analysis of randomized trials. Journal of consulting and clinical psychology, 74(2), 243-252.

Hevey D, Wilczkiewicz E. (2014). ealth-related quality of life following myocardial infarction. Health Psychology and Behavioral Medicine, 2(1):1053-1066.

Jang SN, Kawachi I, Chang J. (2009). Marital status, gender, and depression: Analysis of the baseline survey of the Korean Longitudinal
Study of Ageing (KLoSA). Social Science \&amp; Medicine, 69(11), 1608-1615.

Kahn JH, Garrison AM. (2009). Emotional selfdisclosure and emotional avoidance: Relations with symptoms of depression and anxiety. Joumal of Counseling Psychology, 56(4), 573584.

Kloss JD, Lisman SA. (2002). An exposure-based examination of the effects of written emotional disclosure. British Joumal of Health Psychology, 7(1), 31-46.

Krpan KM, Kross E, Berman MG. (2013). An everyday activity as a treatment for depression: the benefits of expressive writing for people diagnosed with major depressive disorder. Joumal of affective disorders, 150(3), 11481151.

Leopold T. (2018). Gender Differences in the Consequences of Divorce: A Study of Multiple Outcomes. Demography, 55(3), 769797.

Lepore SJ. (1997). Expressive writing moderates the relation between intrusive thoughts and depressive symptoms. Joumal of Personality and Social psychology, 73(5), 1030-1037.

Lorenz FO, Wickrama KA, Conger RD. (2006). The short-term and decade-long effects of divorce on women's midlife health. Joumal of health and social behavior, 47(2), 111-125.

Lovibond PF, Lovibond SH. (1995). The structure of negative emotional states: comparison of the depression anxiety stress scales with the beck depression and anxiety inventories. Behaviour Research and Therapy, 33(3), 335-430.

Mandemakers JJ, Monden CW, Kalmijn M. (2010). Are the effects of divorce on psychological distress modified by family background? Advances in Life Course Research, 15(1), 27 40.

Marry L. Jepson M. (2018). Working with co-partents Taylor and Francis. (10) 18-19.

Mogk C, Otte S, Reinhold-Hurley B, Kroner-Herwig B. (2006). Health effects of expressive writing on stressful or traumatic experiences- a metaanalysis. Psycho-social medicine, 3, Doc.60. 
يوسف گرجى و همكاران

Niles AN, Haltom KE, Mulvenna CM, Lieberman MD, Stanton AL. (2013). Randomized controlled trial of expressive writing for psychological and physical health: the moderating role of emotional expressivity. Anxiety Stress Coping, 27(1), 1-17.

Paivio SC. (2013). Essential processes in emotionfocused therapy. Psychotherapy (Chicago, III), 50(3), 341-345.

Patel M. (2004). Mitochondrial dysfunction and oxidative stress: cause and consequence of epileptic seizures. Free radical biology \& medicine, 37(12), 1951-1962.

Pennebaker JW, Colder M, Sharp LK. (1990). Accelerating the coping process. Joumal of personality and social psychology, 58(3), 528537.

Petrie kJ, Fontanilla L, Thamas MG, Booth RJ, \& Pennebaker JW. (2004). Effects of written Emotional Expression. Psychsomatics Medicine (66), 272-275.

Sakata K, McKenzie CR. (2011). Social security and divorce in Japan. Mathematics and Computers in Simulation, 81(7), 1507-1517.

Sbarra DA. (2015). Divorce and health: current trends and future directions. Psychosomatic Medicine, 77(3), 227-360.

Williams LE, Bargh JA, Nocera CC, Gray JR. (2009). The unconscious regulation of emotion: nonconscious reappraisal goals modulate emotional reactivity. Emotion, 9(6), 847-540.

Zareh H, Shaghaghi F, Dalir M. (2012). The Effect of Writing Disclosure on Severity of Symptoms of OCD and Depression of Individuals with Obsessive-Compulsive Disorder. Joumal of Clinical Psychology, 4(12), 27-34. 